\title{
Correlates of High Technology Exports Performance in the Philippines
}

\author{
Eden J. Garces, Cerenio G. Adriatico \\ College of Business and Management, Southern Leyte State University, San Juan, Philippines \\ Email: edenjgarces@slsuonline.edu.ph
}

How to cite this paper: Garces, E.J. and Adriatico, C.G. (2019) Correlates of High Technology Exports Performance in the Philippines. Open Journal of Social Sciences, 7, 215-226.

https://doi.org/10.4236/jss.2019.75018

Received: April 6, 2019

Accepted: May 24, 2019

Published: May 27, 2019

Copyright $\odot 2019$ by author(s) and Scientific Research Publishing Inc. This work is licensed under the Creative Commons Attribution International License (CC BY 4.0).

http://creativecommons.org/licenses/by/4.0/

\section{(c) (i) Open Access}

\begin{abstract}
This study presents empirical evidence among the predictor variables of foreign direct investment (FDI), energy investment, official development assistance, and gross domestic product (GDP) which have a bearing on the growth of high technology exports in the Philippines. Data sets of indicators used in the study had been downloaded from the World Development Indicators website covering the period 1991-2016. The data were processed and analyzed utilizing the symbolic regression analysis through machine learning, the $\mathrm{Nu}$ tonian Eureqa Desktop. The results of the study revealed that foreign direct investment and official development assistance have significant contributions to the development and manufacture of export-driven commodities classified by the Organization of Economic Cooperation and Development as high technology exports. On the other hand, the gross domestic product has a negative impact while energy investment has no contribution to exports development at all. Further, the results likewise demonstrated that strong causal relationships between high technology exports and the variables evidenced by a very high $\mathrm{R}^{2}$ goodness of fit of 0.82 signifying $82 \%$ of variations in high technology exports could be explained by the predictor variables included in the transfer. The study concluded that two relevant information was obtained. First, the indicator of official development assistance is only suitable in the short run period. Second, the gross domestic product will continue to decline if continuous trade deficit pervades in the long run period.
\end{abstract}

\section{Keywords}

Foreign Direct Investment, Symbolic Regression, Causal Relationships, A Trade Deficit

\section{Introduction}

High technology exports comprise of products with top research and develop- 
ment intensity, such as in aerospace, computers, pharmaceuticals, scientific instruments, and electrical machinery classified both by the World Bank and the Organization for Economic Cooperation and Development. In this age of information technology and globalization, high technology exports are fast becoming one of the key players in the rapid growth of the economy of a particular nation. Seyoum (2015) [1] claimed that in the future high technology products would become the primary attribute in the creation of wealth, accelerated growth in top exports, higher standards of living, economic growth and development. The main purpose of undertaking this study was to examine the determinants of high technology exports in the Philippines. It is on the assumption that the sets of indicators comprising of foreign direct investment, gross domestic product, energy investment, official development assistance, and foreign direct investment played significant roles in transitioning the country toward economic growth and emergence. Anderson and Ejermo (2008) [2] and Kato (2015) [3] ascertained that both knowledge and technology are the critical, essential components in the production of high-quality technology-intensive products geared for distribution in domestic and international markets. The exports of manufactured goods are also observed sensitive to exchange rates in countries and territories like Japan, Hong Kong (China), Korea, China and Taiwan Province (Kato, 2015) [3]. Competitiveness coupled with research and development expenditures should be sufficient and viable enough to establish the level of the technology infrastructure (Porter, 1990) [4] of a particular country desiring to embark in the manufacture of export-oriented goods (Ege, A., and Ege, A.Y., 2017) [5] in order to acquire strong competitiveness (Alemu, 2013) [6] and to become a significant player in the global trade (Zeng, M., 2000, Liu, X.J., 2007, Han, Y.C., 2010) [7] [8] [9]. Porter (1990) [4] also observed that government plays a significant role in the pursuit of excellence in the technology infrastructure by way of deregulating industries, continuously encourage sustained investment in human capital, innovation, and physical assets. The government likewise should support intense local rivalries of competing industries as a stimulus to the creation of competitive advantage. A country having a competitive advantage in the production of a particular good will have an edge in the global market.

Investment in energy projects with private participation covers infrastructure projects in energy (electricity and natural gas transmission and distribution) that have reached financial closure and directly or indirectly serve the public. Movable assets and small projects such as windmills are excluded. The types of projects included are operations and management contracts, operations and management contracts with significant capital expenditure, greenfield projects (in which a private entity or a public-private joint venture builds and operates a new facility), and divestitures. Investment commitments are the sum of investments in facilities and investments in government assets. Investments in facilities are the resources the project company commits to invest during the contract period either in new facilities or in expansion and modernization of existing fa- 
cilities. Investments in government assets are the resources the project company spends on acquiring government assets such as state-owned enterprises, rights to provide services in a specific area, or the use of specific radio spectrums.

Official development assistance (ODA) is a measure of grants, aids, and loans offered by the thirty member-countries of the Organization for Economic Cooperation and Development to the various recipient-developing countries. ODA is widely used as an indicator of international aid flow although it includes some loans. It needs to contain the three elements: the assistance is undertaken by the national governments, with the main purpose of promoting economic development and welfare and concessional financial terms for loans having a grant component of not less than 25\%. Gross domestic product (GDP) is the market value of goods and services produced within a country in a selected interval in time, often a year (Leamer, 2009) [10]. GDP also represents the capstone and grand summary of the world's best system of economic statistics (Anderson, 1993) [11]. The calculation of the GDP can be viewed in three different approaches comprising of the production approach sums the "value added" at each stage of production. Value added is defined as total sales minus the number of intermediate inputs into the production process; the expenditure approach adds up the cost of purchases made by final users, and the income approach sums the incomes generated by production. GDP in a particular country is usually calculated by the national statistical agency, which compiles the information from a large number of sources. In calculating for the GDP, most states follow established international standards contained in the System of National Accounts, 1993, maintained by the International Monetary Fund (IMF), European Commission (EC), Organization for Economic Cooperation and Development (OECD), the United Nations (UN), and the World Bank (WB) (Calen, 2008) [12]. Olson et al. (2014) [13] confirmed by applying simple and multiple regression models both gross domestic product and export of merchandise were observed to be indeed significantly related in the year 2011. Similarly, Khan et al. (2012) [14] suggested trading will be a significant contributor to the robust economy of a country. Foreign direct investment pertains to direct investment equity flows in the host economy. It is the total of equity capital, reinvestment of profits, and other wealth. It includes mergers, acquisition, reinvesting profits, building new facilities and joint venture undertakings. Besides, the investor has to own 10 percent or more of the voting stock to have a controlling interest. According to the World Bank, direct investment is a type of cross-country investments linked with local businesses in one country having significant degree of influence on the management of an enterprise that is resident in another economy. It excludes investment through the purchase of ordinary or preference shares. The World Bank also estimated in 1999 countries like Malaysia and the Philippines, accounted a combined high technology export of $59 \%$ based on the total manufactured goods in that particular year compared to the total output of the United States which account only for 35\%. Issues reflecting on the contribu- 
tion of the inward foreign direct investments included technology spillovers (Marin, et al., 2006) [15], developed financial system (Branstetter, 2006, Hermes, et al., 2003) [16] [17], capital accumulation and output productivity (De Mello, 1999) [18], and transfer of technology (Borensztein, et al., 1998) [19]. Many of the results suggested FDI is an essential vehicle for the removal of technology, relatively contributed more to growth than domestic investment. However, the higher productivity and economic growth fostered by FDI can only be realized when the host country has a minimum threshold stock of human capital and availability of sufficient absorptive capability of the advanced technologies of the recipient economy.

Meanwhile, the manufacture of high technology goods coupled with the utilization of alternative energy resources such as solar, water and wind energy generally reduce consumption of energy. Additionally, firms engaged in the manufacture of export-driven products are now adopting the use of alternative energies to reduce carbon emissions. In reality, however, the contribution of the aggregate amount of high technology exports comprises only a minimal share of the gross domestic product.

However, many of the related researches undertaken focused merely on the overall export performance relative to economic growth (Epaphara, 2016, Olson, et al., 2014, Liu, et al., 1998) [13] [20] [21]. Literature regarding high technology exports was conducted either for developed countries or selected developing countries (Seyum, 2005, Kato, 2015, Bhatt, 2013) [1] [3] [22] including the Philippines were relatively recent. Bhatt (2013) [22] found out foreign direct investment is a significant variable of export indicating a $1 \%$ increase in the inflow of foreign direct investment will lead to at least $0.25 \%$ increase in exports within a one-year time gap with expected gains of both indicators in the long run. Arguably, the country experiences a recurring negative trade balance for many years, and this is the very reason this paper attempted to examine the relevant macroeconomic indicators in determining the growth of high technology exports of the country for the period 1991 until 2016. This will be assessed utilizing the symbolic regression. As recommended by Moreno-Sanchez et al. (2015) [23], symbolic regression (SR) is arguably a new methodology in building a statistical model having its roots in the so-called Genetic Programming. It includes summarizing an algorithm for an automated generation of mathematical expressions in the form of $\mathrm{Y}=\mathrm{f}(\mathrm{x})$ to fit a set of data investigated. Accordingly, the symbolic regression offers some advantages over the standard regression methods like multiple linear regression where Eureqa Nutonian Desktop software can manage in running a search process of potential models while simultaneously evaluating each of them in various criteria finding a model with satisfactory predictive accuracy.

\section{Theoretical and Conceptual Framework}

Contemporary studies provide dimension as to why countries engaged in high 
technology exports consistently sustain balanced economic growth. Based on the related searches there were two determinants contributing to high technology exports namely gross domestic product and foreign direct investment (Bhatt, 2013) [22].

Porter's (1990) [4] diamond theory examined the competitive advantage of nations using a set of variables: gross domestic product, investment in energy, official development assistance and inward foreign direct investment which significantly influence the development of high technology exports in a particular country. Accordingly, the nation's competitiveness largely depends on the capacity of industry to create, redefine, innovate, and upgrade the production of high-quality products ready for distribution at the domestic and international markets. Porter postulated the sample of nations and industries included in the study offered a rich empirical basis for developing and testing the new theory of how countries gain competitive advantage. To achieve this goal, countries, therefore, must move beyond the traditional neo-classical concept of comparative advantage to a competitive edge globally.

Schumpeter's (2017) [24] theory of economic growth argued that business cycles are inevitable in a developing economy due to the uncertainties of economic booms and recessions. It is becoming a recurring phenomenon that cannot be easily removed nor corrected unless the government intervenes. This theory emphasized the creation of new wealth or resources through innovation. Recessions are becoming cyclical in the long run; hence, the need to produce new products that are highly in demand and competitive in the market. The theory also cautions recessions are the price a nation pays for long term economic growth leading to the so-called unnecessary setbacks and damages to the economy.

Rostow's (1959) [25] stages of growth theory postulated economic growth occurs in five primary linear stages of varying length and time starting from a traditional society, setting the preconditions for takeoff into self-sustaining growth, moving into the drive to maturity and the final stage which is the age of mass consumption. Todaro (2015) [26] however thought this as a highly partial theory about modern history. It was argued that while the developed countries had all passed the takeoff into self-sustaining growth, developing countries on the other end were still lagging either in the traditional society or the preconditions for takeoff and had to follow a specific set of rules of development to takeoff transforming them into self-sustaining growth. Foreign direct investment, official development assistance, gross domestic product, energy investment are few of the economic indicators precursor to this 3rd stage of economic growth.

The above diagram (Figure 1) establishes the linkage among the critical variables of HTE. It is hypothesized the variables of foreign direct investment, official development assistance, energy investment, and gross domestic product significantly contribute to the sustained growth of high technology exports in the country, assuming all other things are held constant in the short run period. 


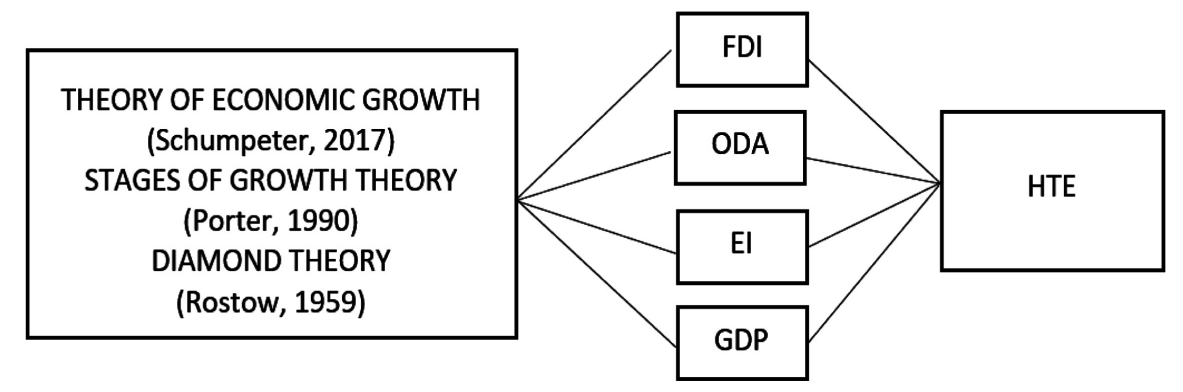

Figure 1. The theoretical and conceptual framework of the study.

\section{Data and Methodology}

The high technology export model utilized in this study is given by:

HTE $=f($ FDI, ODA, EI, GDP) where:

$\mathrm{FDI}=$ foreign direct investment

ODA = official development assistance

$\mathrm{EI}=$ energy investment

GDP $=$ gross domestic product

This model assumes the dynamics of growth of high technology exports are a function of the nation's inward foreign domestic investment, official development assistance received from different bilateral and multilateral agreements, investment in various sources of energy development and the gross domestic product.

This study utilized the available dataset obtained from the World Development Indicators site of the World Bank covering the years 1991 until 2016. It employed an exploratory data analysis using a symbolic regression exploring new information, significant relationship, expand or substantiate existing knowledge, and undertake prediction. The data gathered were processed with the aid of a machine learning, the Nutonian Eureqa Desktop version 1.24.0.9367 under academic license.

The following model definition is being proposed:

$$
y h t e=f((x 1 \text { fdi }),(x 2 \text { gdp }),(x 3 \text { ei }),(x 4 \text { oda }))
$$

where, high technology export is calculated as a function of $(x 1)$ foreign direct investment, $(x 2)$ gross domestic product, $(x 3)$ energy investment, and $(x 4)$ official development assistance.

Further, to arrive at consistent results, the variables were standardized with the use of statistical software. Using the Nutonian Eureqa, Desktop the target expression set in the symbolic regression and the first options containing several formula building blocks already selected by default. Besides, the new formula of sine, cosine, and natural logarithm was checked to conform to linear statistical models. The default error metric was set to absolute error.

\section{Results and Discussion}

Figure 2 shows a general upward trend of high technology exports for the period 


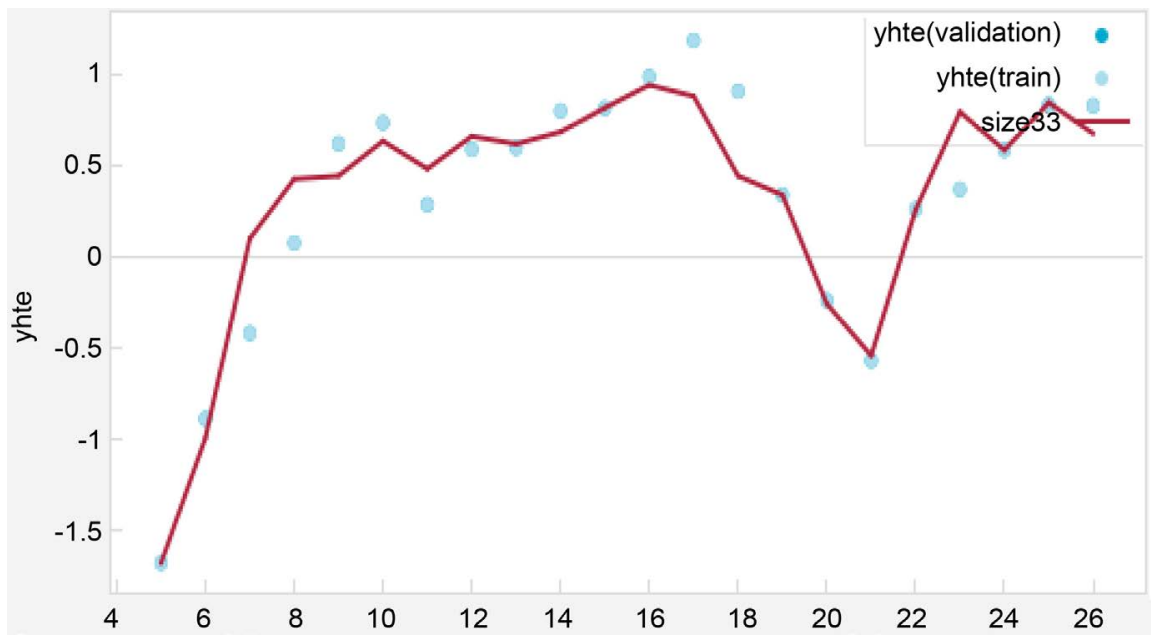

Figure 2. Time series plot of the response variable (Source: Eureqa Nutonian Desktop).

1991-2016. The blue dots represent the actual values of the variable during the past 26 years. The red line, on the other hand, describes the predicted value of high technology exports over time. The graph meanwhile manifested both the dots and the continuous line will reach to convergence at a certain point in the future. It also demonstrates stronger causal relationships among high technology exports and the related macro-economic variables of the country in the long run. If the country continues to manufacture high-quality goods both for domestic consumption and exports all other things are held constant, more foreign direct investments will flow into the country which will create additional jobs to qualified job seekers-highly skilled and semi-skilled bringing unemployment rate at its acceptable level. As determined in previous studies lower unemployment also intensifies the consistent growth of the country's economy (Fuchs, 1980, Islam, 2004, Sodipe and Ogunrinola, 2011, Misztal, 2010 and Wu, 2011) [27] [28] [29] [30] [31]. The massive drop in the high technology exports in 2011 presented in the graph was aggravated by bad weather, weak global demands of electronics, and delays in government spending. As reported by the Center for Research on the Epidemiology of Disasters, 33 natural disasters struck the country in this particular year alone. Typhoon Sendong and other natural disasters that ravaged the different parts of the country caused over 26 billion economic losses and affected livelihood and income of 3.5 million families. Lower demand for electronic exports was also affected by the massive earthquakes and tsunami in Japan, and the very severe flooding in Thailand, a primary source of automotive parts and units. Since Philippine exports were very concentrated in just a single sector, this was severely hit by the global slowdown (the National Economic Development Authority 2012); thus, a considerable drop in exports was accounted in this particular year.

Table 1 which presents the best mathematical model suggested by the software has $\mathrm{R}^{2}$ goodness of fit of 0.82 signifying $82 \%$ of the variation in high technology exports can be explained by the predictor variables included in the transfer function. Of the four identified independent variables consisting of foreign 
Table 1. Selected solution generated from the Pareto Front.

\begin{tabular}{cccccc}
\hline MODEL & $\mathrm{R}^{2}$ & $\begin{array}{c}\text { Mean Squared } \\
\text { Error (MSE) }\end{array}$ & $\begin{array}{c}\text { Number of } \\
\text { Coefficients }\end{array}$ & $\begin{array}{c}\text { Error } \\
\text { Complexity }\end{array}$ \\
\hline $\begin{array}{c}h t e=a+b^{*} o d a+c^{\star} f d i^{*} o d a+ \\
d^{\star} o d a^{3}-e^{*} g d p^{2}-f^{*} o d a^{2}\end{array}$ & 0.82 & 0.17151889 & 6 & Low & Low \\
\hline
\end{tabular}

direct investment, energy investment, official development assistance, and gross domestic product, the variables of gross domestic product and energy investment were observed as not directly significant contributors to the growth of high technology exports. This finding contradicted to the earlier results of Olson et al. (2010) [13], Istaiteyeh and Ismail (2015) [32] suggesting a positive correlation existed between gross domestic product and exports. Although common knowledge dictates that growth in exports contributes positively toward economic growth (Bilas et al., 2015, Xu, 1996) [33] [34] ascertained there is little evidence supporting a causal link between exports and outputs. Accordingly, previous studies also claimed an increase in exports led to a significant increase in gross domestic product.

\section{Model Developed}

$$
h t e=3.49+0.712 o d a+0.578 \text { fdi oda }+0.332 o d a^{3}-0.167 g d p^{2}-1.75 o d a^{2}
$$

In this particular model, it can be understood that high technology exports are primarily a function of foreign direct investment (FDI) and official development assistance (ODA) especially during the initial stage of developing high-end products and goods precisely on short-run. It has to be noted that in the long run and the country has already taken off the production of export-driven consumer products and commodities based on research and development thereby reducing the need to avail for any additional official development assistance in the form of grants and soft loans. The gross domestic product (GDP) on the other hand has a negative bearing due to the trade deficit experienced by the country for several years. While official development assistance provides loans with cheaper interest, the ODA availed by the state from various development partners such as Japan, World Bank, and OECD member countries is for infrastructure, social reform, and community development, respectively. Interestingly, the production of high technology exports no longer require a large amount of energy perhaps due to the advancement in technology as far as manufacturing processes are concerned. On the other hand, traditional production processes such as the manufacture of steel, cement, oil and the like will continue to consume a large number of energy requirements.

The scatter diagram presented in Figure 3 is unable to display a robust positive relationship since the two variables of gross domestic product and energy investment have no positive functional attributes to high technology exports. Additional increase in inflows of foreign direct investment and official development assistance in the production and subsequent distribution of high technology exports will also increase as well. If both indicators of gross domestic product 


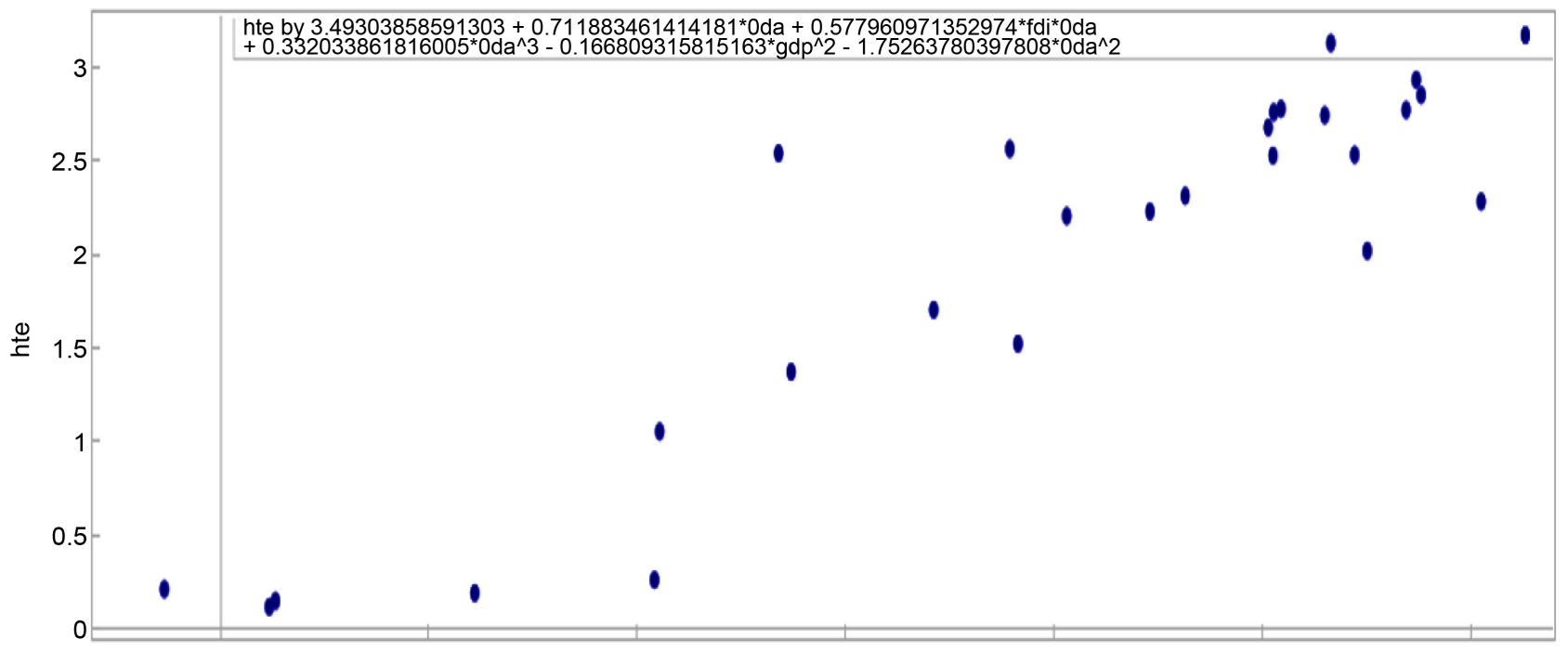

Figure 3. Scatterplot of high technology exports and variables (Source: Eureqa Nutonian desktop).

and energy investment contribute to the production of goods for shipping abroad, a perfect positive correlation would have been attained. This result is further validated by the sensitivity analysis presented in Table 2 .

The sensitivity report indicates a $100 \%$ positive indicating increasing this variable will directly increase the target variable. As discussed earlier, the official development assistance accounts for only $20 \%$ positive for the simple reason in the long run, availing of such aid will reduce gradually. The gross domestic product incurred a $100 \%$ negative impact as a result of the trade deficit. As expected, when exports are higher than imports, a trade surplus will be achieved that would significantly contribute to an increase in the nation's outputs.

Overall, the model generated likewise is found to have high adjusted R-squared, high correlation coefficient and low mean absolute error. It indicated the predicted variables of foreign direct investment and official development assistance showed the combined positive magnitude based on the sensitivity analysis. High technology exports were significantly dependent on the two predictor variables. Moreover, increases in these variables lead to improvements in the target variable, generally indicating how significant the positive impact was. If the trend results continue to generate a positive outlook for the Philippines in the long run, the country will become better off in terms of holistic economic growth and development. Porter's (1990) [4] diamond theory which proposed the establishment of a framework for development likewise suggested the integration of highly skilled human capital, resource endowment, innovation, and capital in the national development plan and agenda of a particular country. In the absence of a single component, any development efforts will lead to nowhere. As in the case of the Philippines, the nation has been lethargic for decades and was often labeled as the "sick man of Asia". It cannot be argued that increased production of goods geared for domestic and export will reduce the likelihood of unemployment. Hence, policymakers should be sensible in developing agenda and 
Table 2. Sensitivity analysis results of the target variables.

\begin{tabular}{cccccc}
\hline Variable & Sensitivity & \% Positive & $\begin{array}{c}\text { Positive } \\
\text { Magnitude }\end{array}$ & \% Negative & $\begin{array}{c}\text { Negative } \\
\text { Magnitude }\end{array}$ \\
\hline ODA & 1.1985 & $20 \%$ & 1.1829 & $80 \%$ & 1.2024 \\
FDI & 0.77774 & $100 \%$ & 0.77774 & $0 \%$ & 0 \\
GDP & 0.52227 & $0 \%$ & 0 & $100 \%$ & 0.52227 \\
\hline
\end{tabular}

Source: Eureqa Nutonian desktop.

policy instruments with a focus on research and development that will bring the country towards continued sustained growth and prosperity.

\section{Conclusion}

There are two relevant facts obtained in this particular study. First, official development assistance is suitable only in the short-term not on the long term basis. Hence, inflows of this indicator should be channeled into the creation of innovative programs and activities rather than focusing on the development projects. Second, the gross domestic product continues to decrease if consumers spend more on buying and consuming foreign goods rather than patronizing goods sold by local producers. As such, there is a continuing need to educate consumers on the impact of the trade deficit. Foreign direct investment and official development assistance are two important macroeconomic indicators necessary for the full development of goods classified as high technology efforts. It is pervasive that over the years, the country suffered a significant setback in global trade due to continued trade deficits detrimental to the nation's economy as this likewise increases in foreign debt. Economists, however, agree that trade deficits are sustainable as long as it does not exceed 3\% of the nation's gross domestic product (GDP) in the long run. The world is now increasingly migrating into industry 4.0 and to be able to keep at pace with the recent development policymakers who have to put more teeth in the creation of wealth through innovation. Initially, it requires a comprehensive development planning participated by the academe, the industry and relevant sectors. Finally, the use of symbolic regression (SR) will offer unbiased statistical results in future research.

\section{Conflicts of Interest}

The authors declare no conflicts of interest regarding the publication of this paper.

\section{References}

[1] Seyoum, B. (2005) Determinants of Levels of High Technology Exports an Empirical Investigation. Advances in Competitiveness Research, 13, 64-79. https://search.proquest.com/docview/211368444?accountid=173015

[2] Andersson, M. and Ejermo, O. (2008) Technology Specialization and the Magnitude and Quality of Exports. Economics of Innovation and New Technology, 17, 355-375. https://search.proquest.com/docview/219947792? accountid=173015 
https://doi.org/10.1080/10438590701279714

[3] Kato, A. (2015) Effects of Exchange Rate Changes on East Asian Technology-Intensive Exports. The Journal of International Trade \& Economic Development, 24, 809-821. https://doi.org/10.1080/09638199.2014.974659 https://search.proquest.com/docview/1689380723?accountid=173015

[4] Porter, M.E. (1990) The Competitive Advantage of Nations. Competitive Intelligence Review, 1, 14. https://doi.org/10.1002/cir.3880010112

[5] Ege, A. and Ege, A.Y. (2017) The Turkish Economy and the Challenge of Technology: A Trade Perspective. New Perspectives on Turkey, 57, 31-60.

https://search.proquest.com/docview/1960941600?accountid=173015 https://doi.org/10.1017/npt.2017.28

[6] Alemu, A.M. (2013) The Nexus between Technological Infrastructure and Export Competitiveness of High-Tech Products in East Asian Economies. Journal of Economic Development, Management, IT, Finance, and Marketing, 5, 14-26. https://search.proquest.com/docview/1509736725? accountid=173015

[7] Zeng, M. (2000) High Technology to Boost Exports. China Daily. https://search.proquest.com/docview/257609515?accountid=173015

[8] Liu, X.J. (2007) The Analysis of Technology Importation Effect on Comparative Advantage of High-Tech Products Export (Order No. H211077). ProQuest Dissertations \& Theses Global.

https://search.proquest.com/docview/1026529488?accountid=173015

[9] Han, Y.C. (2010) An Evaluative Research on High-Tech Products Export Competitiveness in China (Order No. 10386123). ProQuest Dissertations \& Theses Global. https://search.proquest.com/docview/1868345565?accountid=173015

[10] Leamer, E.E. (2009) Gross Domestic Product. In: Leamer, E.E., Ed., Macroeconomic Patterns and Stories, Springer, Berlin, 19-38.

[11] Anderson, L. (1993) Gross Domestic Product. The Concise Encyclopedia of Economics. Library of Economics and Liberty.

[12] Callen, T. (2008) What Is Gross Domestic Product? Finance \& Development, 45.

[13] Olson, M., Pilcher, S. and Whitman, N. (2014) Empirical Analysis of the Relationship between Exports and GDP.

[14] Khan, M., Ferdous, T. and Kundu, N. (2012) Future Contribution of Export and Import to GDP in Bangladesh: A Box-Jenkins Approach.

[15] Marin, A. and Bell, M. (2006) Technology Spillovers from Foreign Direct Investment (FDI): The Active Role of MNC Subsidiaries in Argentina in the 1990s. The Journal of Development Studies, 42, 678-697. https://doi.org/10.1080/00220380600682298

[16] Branstetter, L. (2006) Is Foreign Direct Investment a Channel of Knowledge Spillovers? Evidence from Japan's FDI in the United States. Journal of International Economics, 68, 325-344. https://doi.org/10.1016/j.jinteco.2005.06.006

[17] Hermes, N. and Lensink, R. (2003) Foreign Direct Investment, Financial Development, and Economic Growth. The Journal of Development Studies, 40, 142-163. https://doi.org/10.1080/00220380412331293707

[18] De Mello, L.R. (1999) Foreign Direct Investment-Led Growth: Evidence from Time Series and Panel Data. Oxford Economic Papers, 51, 133-151. https://doi.org/10.1093/oep/51.1.133

[19] Borensztein, E., De Gregorio, J. and Lee, J.W. (1998) How Does Foreign Direct Investment Affect Economic Growth? Journal of International Economics, 45, 115-135. 
https://doi.org/10.1016/S0022-1996(97)00033-0

[20] Epaphra, M. (2016) Determinants of Export Performance in Tanzania. Journal of Economics Library, 3, 470-487.

[21] Liu, L.G. and Graham, E.M. (1998) The Relationship between Trade and Foreign Investment: Empirical Results for Taiwan and South Korea (No. WP98-7).

[22] Bhatt, P.R. (2013) Causal Relationship between Exports, FDI and Income: The Case of Vietnam. Applied Econometrics and International Development, 13, 161-172.

[23] Moreno-Sanchez, D. and Tijerina-Aguilera, J. (2015) Use of Symbolic Regression for Lean Six Sigma Projects.

[24] Schumpeter, J.A. (2017) Theory of Economic Development. Routledge, Abingdon-on-Thames. https://doi.org/10.4324/9781315135564

[25] Rostow, W.W. (1959) The Stages of Economic Growth. The Economic History Review, 12, 1-16. https://doi.org/10.1111/j.1468-0289.1959.tb01829.x

[26] Todaro, M.P. and Smith, S.C. (2011) Economic Development. 11th Edition, Prentice Hall, Harlow.

[27] Fuchs, V.R. (1980) Economic Growth and the Rise of Service Employment. https://doi.org/10.3386/w0486

[28] Islam, R. (2004) The Nexus of Economic Growth, Employment and Poverty Reduction: An Empirical Analysis.

[29] Sodipe, O.A. and Ogunrinola, I.O. (2011) Employment and Economic Growth Nexus in Nigeria. International Journal of Business and Social Science, 2, 12-17.

[30] Misztal, P. (2010) Foreign Direct Investments, as a Factor for Economic Growth in Romania. Journal of Advanced Studies in Finance, 1, 72-82. https://search.proquest.com/docview/862561889?accountid=173015

[31] Wu, Y. (2011) Empirical Analysis on the Relationship between Employment and Economic Growth of Guangdong Province (Order No. 10576829). ProQuest Dissertations \& Theses Global. https://search.proquest.com/docview/1873860868?accountid=173015

[32] Istaiteyeh, R.M.S. and Ismail, M.T. (2015) A Causal Relationship between Foreign Direct Investment, Economic Growth and Export: Empirical Case for Jordan. Advances in Management and Applied Economics, 5, 19-30.

https://search.proquest.com/docview/1704498162?accountid=173015 https://doi.org/10.15520/jbme.2016.vol4.iss5.186.pp01-06

[33] Bilas, V., Bosnjak, M. and Franc, S. (2015) Examining the Export-Led Growth Hypothesis: The Case of Croatia. Nase Gospodarstvo, 61, 22-31.

https://search.proquest.com/docview/1699250795?accountid=173015 https://doi.org/10.1515/ngoe-2015-0010

[34] Xu, Z. (1996) On the Causality between Export Growth and GDP Growth: An Empirical Reinvestigation. Review of International Economics, 4, 172-184. https://doi.org/10.1111/j.1467-9396.1996.tb00094.x 